\title{
Cellular distribution of beta-trace protein in CNS and brain tumours
}

\author{
J.-E. OLSSON, C. BLOMSTRAND, AND K. G. HAGLID \\ From the Department of Neurology, University Hospital, Lund, \\ and Institute of Neurobiology, Medical Faculty, University of Göteborg, Sweden
}

SYNOPSIS The low-molecular weight beta-trace protein constitutes about seven per cent of the total protein content in human cerebrospinal fluid. Within the central nervous system the protein is found predominantly in white matter and fractions enriched in glial cells. Immunofluorescence studies on sections of monkey brains show that beta-trace protein is particularly localized to cells such as astrocytes and oligodendrocytes. Significantly higher amounts of beta-trace protein are found in brain tumours derived from glial cells than in other tumours.

With the aid of immunoelectrophoresis using antisera against cerebrospinal fluid (CSF), betatrace protein was found in CSF (Clausen, 1961), in urine, and in ascitic fluid (Hochwald and Thorbecke, 1962). Beta-trace protein has a low molecular weight of 31,000 , but is one of the major CSF proteins, constituting about $7 \%$ of the total protein concentration of normal human CSF (Link, 1967). Recently, the concentration in serum was established (Olsson, Link, and Nosslin, 1973) at about seven times lower than that in CSF.

Elevated concentrations of beta-trace protein in CSF have been found in patients with severe brain damage due to cerebrovascular disorders (Ericsson, et al., 1969; Link and Olsson, 1972). There are also some indications of increased concentration of beta-trace protein in CSF during exacerbations of multiple sclerosis (Olsson and Link, 1973b).

The highest amounts of beta-trace protein were found in extracts of white matter of the central nervous system (CNS); but also extracts of grey matter and of genital organs, especially epididymis, were found to contain rather high concentrations of beta-trace protein (Olsson and Link, 1973a; Olsson and Nord, 1973).

Its high concentration in human CSF and the high amounts of beta-trace protein in white CNS

Address for correspondence: Dr. J.-E. Olsson, Department of Neurology, University Hospital, S-221 85 Lund, Sweden. matter make the distribution within the CNSo 4 especially interesting, and the purpose of the present investigation is to elucidate the CNS? cellular distribution of beta-trace protein.

\section{MATERIALS}

BRAIN AND TUMOUR TISSUES Three human brains were obtained at necropsy within 12 hours aftet death from patients who had died without any detectable signs of disease of the nervous system or the genital system. Two brains were received from squirrel monkeys, killed by intracardial perfusion with Ringer's solution in mebumal anaesthesia. The brains were then immediately used for preparations enriched in neuronal and glial fractions, as well as preparations of water-soluble protein extracts of grey and white matter. One monkey brain was used for immunofluorescence studies.

Brain tumour tissues were obtained from operations at the Department of Neurosurgery, Sahlgren Hospital, Gothenburg. The tissue pieces were placed on ice immediately after operation and were dissected free from surrounding meninges, blood vessels, and normal brain tissue. Extraction of watersoluble proteins and quantitation of beta-trace protein was performed as described below.

Cerebrospinal fluid and serum were obtained from $\frac{7}{O}$ 66 patients with tumours within the CNS. The samples were taken over three years, 1970 to 1972 , at $N$ the Department of Neurology, University Hospital, Lund, from patients later operated on at the Department of Neurosurgery. Thus, histological diagnosis was obtained from all except six patients with intra- 
TABLE 1

AGE DISTRIBUTION OF HEALTHY CONTROLS AND PATIENTS WITH DIFFERENT CNS TUMOURS

\begin{tabular}{|c|c|c|c|c|c|c|c|c|}
\hline \multirow[t]{2}{*}{ Diagnosis } & \multirow{2}{*}{$\begin{array}{c}\text { Number } \\
\text { of } \\
\text { cases }\end{array}$} & \multicolumn{6}{|c|}{ Age $(y r)$} & \multirow{2}{*}{$\begin{array}{c}\text { Mean } \\
\text { age } \\
(y r)\end{array}$} \\
\hline & & $20-30$ & $31-40$ & $41-50$ & $51-60$ & $61-70$ & $>70$ & \\
\hline Healthy controls & 19 & & 2 & 3 & 7 & 6 & 1 & 55 \\
\hline \multicolumn{9}{|l|}{ Brain tumours } \\
\hline Malignant glioma & 16 & & & 4 & 2 & 8 & 2 & 61 \\
\hline Other gliomas & 11 & 1 & & 3 & 3 & 3 & 1 & 55 \\
\hline Ependymoma & 2 & & & & 2 & & & 56 \\
\hline Meningioma & 10 & 1 & 1 & 1 & 2 & 5 & & 54 \\
\hline Acoustic neurinoma & 2 & 1 & & & 1 & & & 42 \\
\hline Metastatic tumours & 3 & & & & & 2 & 1 & 69 \\
\hline Miscellaneous* & 2 & & & & 1 & 1 & & 58 \\
\hline \multicolumn{9}{|c|}{ Spinal canal tumours } \\
\hline \multicolumn{9}{|c|}{ Extramedullary tumours } \\
\hline Meningioma & 6 & & & & 1 & 4 & 1 & 67 \\
\hline Neurinoma & 4 & 1 & & 1 & 2 & & & 44 \\
\hline Miscellaneous $\dagger$ & 3 & 1 & & & & 2 & & 52 \\
\hline \multicolumn{9}{|c|}{ Intramedullary tumours } \\
\hline Unknown & 6 & & & 4 & 1 & & 1 & 55 \\
\hline Ependymomas & 1 & & & $i$ & & & & 47 \\
\hline
\end{tabular}

* Haemangioma (1); congenital cystic tumour (1).

+ Haemangioma (1); lipoma (1); metastatic tumour (1).

medullary tumours, which not were removed. The samples were analysed for the concentration of total protein and beta-trace protein, stored at $-20^{\circ} \mathrm{C}$, and the quantifications performed simultaneously.

As the concentration of beta-trace protein in CSF increases with age (Link and Olsson, 1972), a control group, consisting of CSF and serum from 19 age matched 'healthy' persons, was analysed simultaneously. These samples were obtained from patients investigated at the neurological department for minor psychoneurotic disorders-for example, tension headache. All CSF samples had a normal cell count-that is, less than five leucocytes $/ \mathrm{mm}^{3}$, and a normal protein concentration-that is, less than $46 \mathrm{mg} / 100 \mathrm{ml}$ up to age 45 years, thereafter increasing with age.

Table 1 records the age of the patients and the different histological diagnoses of the tumours.

PREPARATION OF BETA-TRACE PROTEIN AND ANTISERUM AGAINST BETA-TRACE PROTEIN Beta-trace protein was prepared from human CSF, as described by Link (1967). The purity of the protein was controlled by agar gel electrophoresis performed on microscopic slides, according to Wieme (1959), under conditions previously described (Link and Müller, 1971), where only three distinct fractions characteristic for beta-trace protein could be seen between the $\mathscr{T}$-fraction and the gamma ${ }_{4}$-globulin fraction. The protein was also tested by immunoelectrophoresis with antiserum against CSF, where one precipitation line, extending from the alpha $a_{2}$-region to the middle of the gamma-region was found.

Antiserum against beta-trace protein was prepared by immunization of one rabbit with the purified protein. The rabbit received $1 \mathrm{mg}$ beta-trace protein mixed with $0.4 \mathrm{ml}$. physiological saline and $0.4 \mathrm{ml}$. of Freund's complete adjuvant (Difco Laboratories, Detroit, U.S.A.) injected into the toepads. Similar injections were repeated after one, two, and four months. At the two last injections, half of the dose was given. Two weeks after each of the last two injections, the rabbit was bled by ear. The antiserum thus obtained was somewhat contaminated with antibodies against IgG and gamma-trace protein, as tested by immunoelectrophoresis against human CSF and serum, but after two absorptions with human serum (antiserum and serum in proportion $1: 10$ at $37^{\circ} \mathrm{C}$ during one hour) these contaminations disappeared, and the antiserum gave only one precipitation line on immunoelectrophoresis identical with that of beta-trace protein.

\section{METHODS}

PREPARATIONS OF FRACTIONS ENRICHED IN NEURONAL PERIKARYA AND GLIAL CELlS Neuronal and glial cell-enriched fractions were prepared, as previously described by Blomstrand and Hamberger (1969, 1970). The cooled brains were chopped in a mechanical chopper and incubated at $37^{\circ} \mathrm{C}$ for 45 minutes. The suspended tissue was further fragmented at $0^{\circ} \mathrm{C}$ 
by passage through nylon meshes. The resulting suspension was filtered through a series of nylon meshes with pore sizes down to $50 \mu \mathrm{m}$. The filtrate was centrifuged for five minutes at $150 \mathrm{~g}$, and the resulting pellet was mixed with Ficoll (Pharmacia Fine Chemicals, Upsala, Sweden) to a final Ficoll concentration of $20 \%$. The fractions were centrifuged on a discontinuous sucrose-Ficoll gradient for 120 minutes at $81,500 \mathrm{~g}$. The neuronal fraction was collected below the $30 \%$ Ficoll interphase and the glial fraction at the $12 / 15 \%$ Ficoll interphase. The fractions were resuspended in a large volume of $0.32 \mathrm{M}$ sucrose and collected by centrifugation at $2,000 \mathrm{~g}$ for 20 minutes. The different fractions were checked by the light microscope after staining with methylene blue.

PREPARATIONS OF WATER-SOlUble PROTEINS Preparations of water-soluble proteins from human brains as well as cell enriched fractions and brain tumours, were obtained at homogenization at $0^{\circ} \mathrm{C}$ with isotonic sucrose solution. The soluble proteins were separated from particulate material by centrifugation at $38,000 \mathrm{~g}$ for 30 minutes at $0^{\circ} \mathrm{C}$. The supernatants were pipetted off. This procedure was repeated twice on the homogenate after dissolution with the same volume of the sucrose solution as initially used for homogenization. The three supernatants were pooled and stored at $-20^{\circ} \mathrm{C}$ until use.

DETERMINATION OF BETA-TRACE PROTEIN The concentration of beta-trace protein in the fractions of neuronal and glial cells, in the extracts of grey and white CNS matter, as well as the extracts of tumours, was determined by complement fixation, principally as described by Moore and Perez (1968), and by Haglid et al. (1973). The tissue extracts were diluted in $\mathrm{NaCl}$-veronal buffer containing $\mathrm{Ca}^{++}$and $\mathrm{Mg}^{++}$ and $0.1 \%$ gelatin. Complement (freshly prepared, or stored at $-80^{\circ} \mathrm{C}$ for not more than three weeks), haemolysin, and sheep red cells were obtained from the Department of Bacteriology, Sahlgren Hospital, Gothenburg. Assays were made in duplicate in $3 \mathrm{ml}$ Pyrex tubes, which had been siliconized with SC-87 Dry Film (General Electric Company). With each assay, standards of purified beta-trace protein, ranging from $0.06 \mu \mathrm{g}$ to $4 \mu \mathrm{g} / \mathrm{ml}$ were used. Ten microlitres of samples (standard, tissue extract, or veronal buffer blanks) were pipetted into siliconized tubes; thereafter $100 \mu \mathrm{l}$ complement and antiserum was added. Complement was diluted 1:300-400 to produce $50 \%$ haemolysis of sensitized sheep red cells. To a further two tubes of each dilution of standard protein, tissue extracts, and antiserum, complement was added as a control for anticomplementary activity. At dilutions of tissue extract used for calculation ( $50 \%$ haemolysis), anticomplementary activity was always negligable.

Antiserum against beta-trace protein was pretreated at $56^{\circ} \mathrm{C}$ for 20 minutes and diluted 1:1000; this contained sufficient antibody to give maximum fixation of complement in the presence of different amounts of antigen. Fixation of complement was carried out at $+4^{\circ} \mathrm{C}$ for 19 hours under Para film cover; thereafter $100 \mu \mathrm{l}$ sensitized sheep red cells, suspended in veronal buffer, and $0.5 \mathrm{ml}$ veronal buffer were added. The concentration of sheep red cells was always such that complete haemolysis gave an absorbance of approximately 1.0 at $413 \mathrm{~nm}$. Tubes were then incubated under Para film cover for 60 minutes at $37^{\circ} \mathrm{C}$ in a shaking water-bath, with vigorous shaking by hand every 10 minutes in order to ensure uniform suspension of red cells. Haemolysis was stopped by quenching in an ice-bath, and the tubes were centrifuged for five minutes at $3,000 \mathrm{rpm}$ in a cold room $\left(+4^{\circ} \mathrm{C}\right)$. The degree of haemolysis was then determined from the absorbance of the supernatant at $413 \mathrm{~nm}$.

Quantification of beta-trace protein in CSF and serum was performed by single radial immunodiffusion (Mancini et al., 1964). Ten microlitres unconcentrated CSF and $20 \mu \mathrm{l}$ unconcentrated serum were applied at every determination. All analyses were carried out simultaneously. The standard for the determinations of beta-trace protein consisted of known dilutions of the purified protein that had beeno isolated from human CSF, as described (Link, 1967) The lower limit for detection of beta-trace protein was $0.25 \mathrm{mg}$ per $100 \mathrm{ml}$.

DETERMINATION OF TOTAL PROTEIN The protein concentration in standard solutions used for quantification of beta-trace protein, CSF samples, preparations of brain fractions, and CNS tumours was determined by a modification (Bailey, 1962) of the method described by Lowry et al., 1951.

IMMUNOFLUORESCENCE Immunofluorescence investigations were performed according to the multiplelayer method, described by Coons $(1957,1958)$. Cryostat sections $5 \mu$ thick of the frozen specimens of cerebral and cerebellar monkey hemispheres were first dried and subsequently fixed in cold acetone for 30 seconds. Out of every three sections, the first was covered with antiserum against human beta-trace protein; the second was covered with antiserum against human beta-trace protein, repeatedly absorbed with the purified protein until no precipitate was seen; and the third was treated with buffered saline instead of antiserum. An immunological identity between human and monkey beta-trace protein has earlier been demonstrated (Olsson and Nord, 


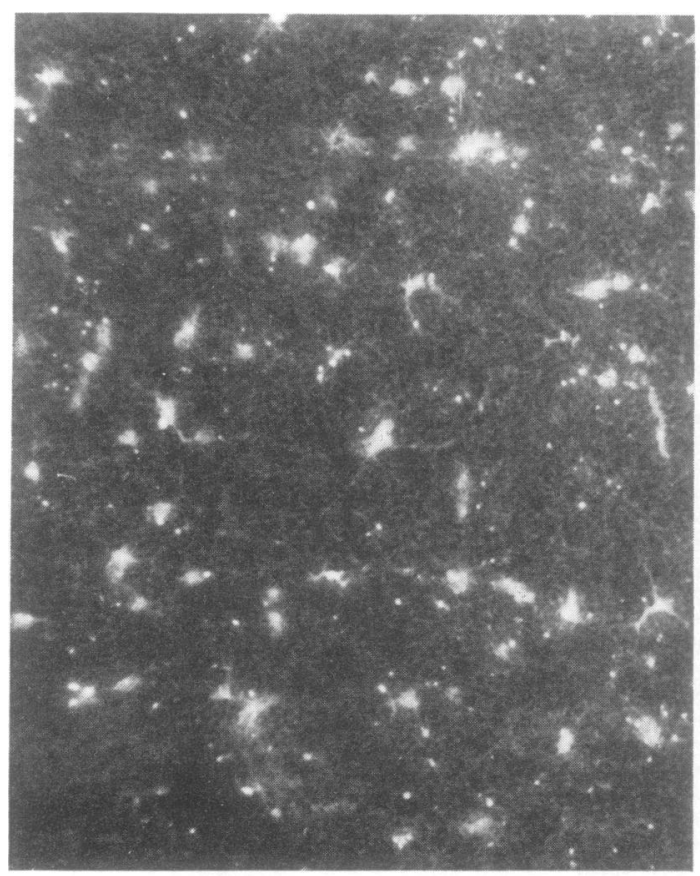

(a)

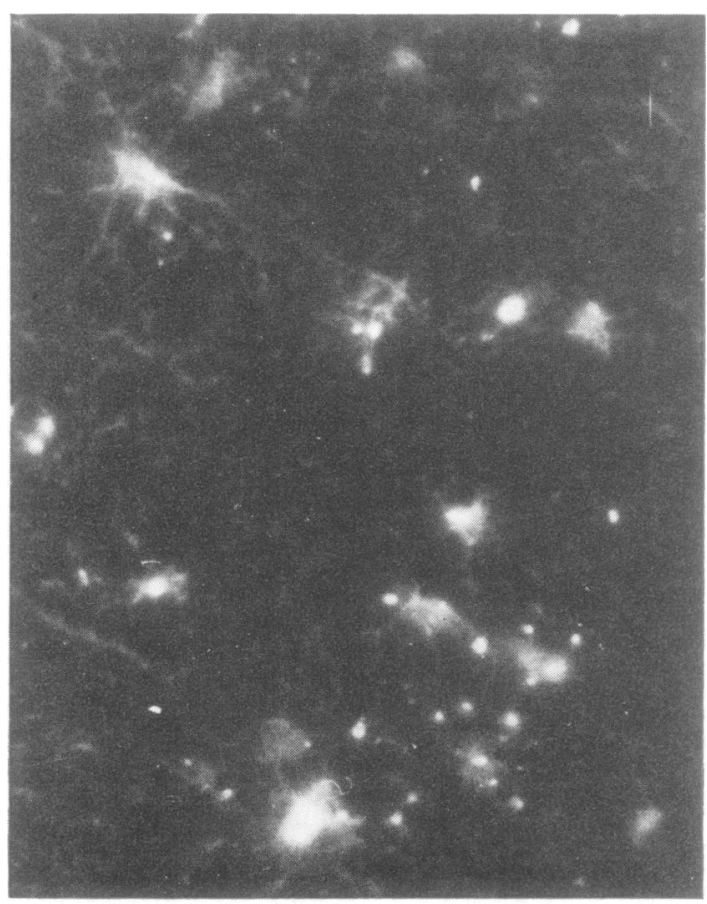

(b)

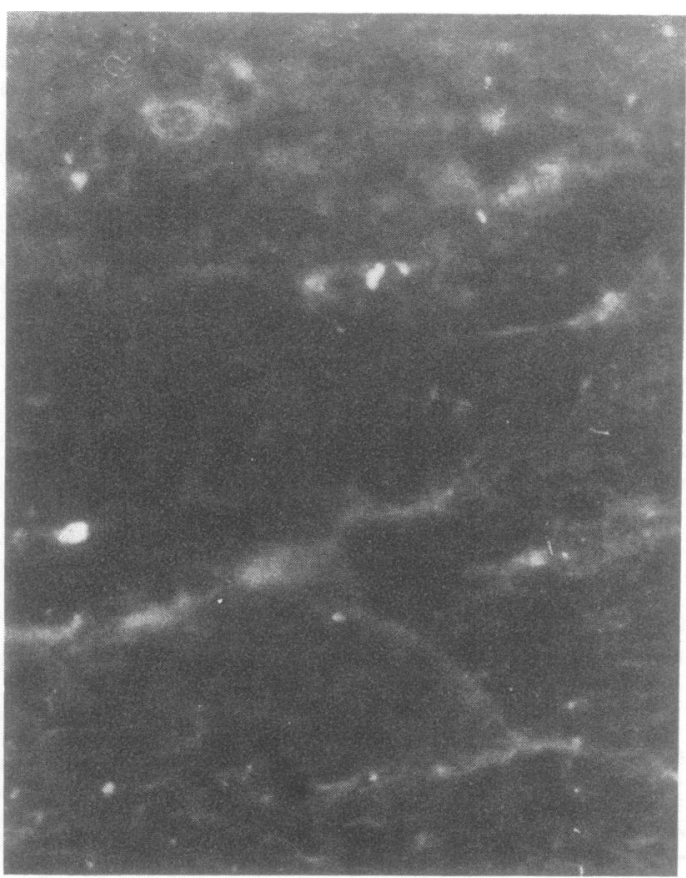

(c)

FIGURE (a), (b), and (c) $5 \mu$ cryostat sections through cerebral matter of normal squirrel monkey. The sections are treated with antiserum against human beta-trace protein. Specific immunofluorescence is seen in glial cells, which have an appearance like that of astrocytes and oligodendrocytes. The small, spotlike fluorescence seen is yellow and unspecific, probably deriving from lipofuscein bodies. (a) $\times 160$. (b) $\times 250$. (c) Specific immunofluorescence in a glial cell, probably an astrocyte, $\times 400$.

1973). After washing for five minutes in buffered saline, the sections were covered with these solutions in dilution $1: 2$ for 30 minutes. After thorough washing (three $\times$ five minutes) in cold phosphate buffered saline, pH 7·1, a goat anti-rabbit globulin gammaglobulin conjugated with fluorescein isothiocyanate (Difco Laboratories, Detroit, U.S.A.) was applied to the sections for 30 minutes. Excess fluorescent antibody was then removed by repeated washings (three $x$ five minutes) with buffer. Both test and control sections were run in parallel. Antiserum and absorbed antiserum were diluted serially, and test control fluorescence differences were optimum at dilutions 1:10 of the antiserum and the absorbed antiserum.

The sections were mounted in buffered glycerol 
(nine parts of glycerol, one part of buffered saline) under a coverslip and immediately examined under a Zeiss fluorescence microscope equipped with an Osram HBO high pressure mercury lamp, fitted with a BG 12 filter (3 mm; Schott \& Gen., Germany). The condenser was a darkfield oil immersion condenser (Carl Zeiss); the secondary filter was an OG 4 filter (Schott \& Gen.). For immunofluorescence microphotographs, Gevaert Scopix G film was used, the exposure times ranging from 1 to 10 minutes.

IMMUNODIFFUSION Antiserum against human betatrace protein and the purified protein was assayed against such brain specific antigens as the S-100 protein (Moore, 1965), the 14-3-2 protein (Moore and Perez, 1968), and the human alpha $a_{2}$ glycoprotein (Warecha and Bauer, 1966), as well as antisera against these antigens by means of double diffusion in agar plates, according to the method of Ouchterlony (1948).

The S-100 protein and antiserum against S-100 were prepared as described by Haglid et al. (1973), the 14-3-2 protein and the human alpha $_{2}$ glycoprotein and their antisera were generously provided by Dr. B. W. Moore and Dr. K. Warecka respectively.

STATISTICAL METHODS Wilcoxon's rank sum test was used for comparison of the values of beta-trace protein and total protein concentration in the different tumour and control groups.

\section{TABLE 2}

CONCENTRATIONS OF WATER SOLUBLE BETA-TRACE PROTEIN AND S-100 PROTEIN, GIVEN IN RELATION TO THE TOTAL WATER SOLUBLE PROTEIN CONTENT IN EXTRACTS OF DIFFERENT PARTS OF HUMAN AND MONKEY CNS, DIFFERENT CELLULAR FRACTIONS OF CNS AND HUMAN EPIDIDYMIS

\begin{tabular}{lcc}
\hline Material & $\begin{array}{c}\text { Beta-trace protein } \\
(\mu \mathrm{g} / \mathrm{mg} \text { water } \\
\text { soluble protein })\end{array}$ & $\begin{array}{c}\text { S-100 protein } \\
(\mu \mathrm{g} / \mathrm{mg} \text { water } \\
\text { soluble protein })\end{array}$ \\
\hline Normal human brain & 1.2 & 5.3 \\
$\quad$ Grey matter & 3.3 & 17.7 \\
White matter & 0.6 & 1.0 \\
Neuronal fractions & 1.7 & 5.3 \\
Glial cells fractions & 1.6 & 0.0 \\
Normal human epididymis & & - \\
Normal monkey brain & 0.16 & - \\
$\quad$ Whole suspension & 0.06 & - \\
$\quad$ Neuronal fractions & 0.35 & \\
Glial fractions & & \\
\hline
\end{tabular}

\section{RESULTS}

With the double diffusion technique in agar, no immunological cross-reaction could be found between beta-trace protein, S-100, 14-3-2, and alpha $_{2}$ glycoprotein.

Table 2 gives the quantification of water soluble beta-trace protein. The values are expressed as $\mu \mathrm{g}$ beta-trace protein per $\mathrm{mg}$ of soluble protein. For comparison, earlier published values of the brain specific protein S-100, similarly estimated in the same tissue samples, are shown (Haglid et al., 1973).

Water soluble protein recovered from grey and white CNS matter was almost identical per wet weight. The amount of water soluble betatrace protein was about three times higher in white CNS matter than in grey. Similar differences in concentration were found between both human and monkey fractions enriched in glial cells and neuronal cells.

\section{TABLE 3}

CONCENTRATIONS OF WATER SOLUBLE BETA-TRACE PROTEIN AND S-100 PROTEIN, GIVEN IN RELATION TO TOTAL WATER SOLUBLE PROTEIN CONTENT IN EXTRACTS OF DIFFERENT BRAIN TUMOURS

\begin{tabular}{lcc}
\hline Type of tumour tissue & $\begin{array}{c}\text { Beta-trace protein } \\
(\mu g / \text { mg water } \\
\text { soluble protein })\end{array}$ & $\begin{array}{c}\text { S-100 protein } \\
(\mu g / m g \text { water } \\
\text { soluble protein })\end{array}$ \\
\hline Astrocytoma & 16.7 & 6.9 \\
Astrocytoma & 5.2 & 17.7 \\
Astrocytoma & 7.0 & 4.5 \\
Astrocytoma & 10.9 & 8.2 \\
Oligodendroglioma & 4.3 & 1.2 \\
Glioma (unspecified) & 10.3 & 4.6 \\
Ependymoma & 0.1 & 0.0 \\
Ependymoma & $<0.1$ & 0.0 \\
Ependymoma & 0.0 & 0.0 \\
Meningioma & 0.1 & 0.0 \\
Meningioma & 0.0 & 0.0 \\
Meningioma & 0.0 & 0.0 \\
Metastasis & $<1.2$ & 0.0 \\
Metastasis & 0.0 & 0.0 \\
Metastasis & 0.0 & 0.0 \\
& & \\
\hline
\end{tabular}

Table 3 lists the concentrations of water soluble beta-trace protein in the extracts of human brain tumours. Considerably higher values were found in tumours of glial cell origin, than in tumours differentiated from cells of different origins-for example, meningiomas, which are formed from the mesodermal layer 
TABLE 4

CONCENTRATION OF BETA-TRACE PROTEIN IN SERUM AND CSF AND TOTAL PROTEIN CONCENTRATION IN CSF IN PATIENTS WITH CNS TUMOURS AND 'HEALTHY' CONTROLS

\begin{tabular}{|c|c|c|c|c|}
\hline \multirow[t]{2}{*}{ Diagnosis } & \multirow{2}{*}{$\begin{array}{l}\text { Number } \\
\text { of } \\
\text { cases }\end{array}$} & \multirow{2}{*}{$\begin{array}{c}\text { Total } \\
\text { protein } \\
\text { CSF }(m g \%)\end{array}$} & \multicolumn{2}{|c|}{ Beta-trace protein } \\
\hline & & & $C S F(m g \%)$ & $\operatorname{serum}(m g \%)$ \\
\hline Healthy controls & 19 & $41 \pm 2.43$ & $2 \cdot 6 \pm 0 \cdot 132$ & $0.47 \pm 0.070$ \\
\hline $\begin{array}{l}\text { Brain tumours } \\
\text { Malignant glioma } \\
\text { Other gliomas } \\
\text { Ependymoma } \\
\text { Meningioma } \\
\text { Acoustic neurinoma } \\
\text { Metastasis } \\
\text { Miscellaneous* }\end{array}$ & $\begin{array}{r}46 \\
16 \\
11 \\
2 \\
10 \\
2 \\
3 \\
2\end{array}$ & $\begin{array}{l}78 \pm 7 \cdot 14 \\
89 \pm 11 \cdot 23 \\
69 \pm 12 \cdot 38 \\
43 \pm 23 \cdot 00 \\
66 \pm 6 \cdot 32 \\
178 \pm 109 \cdot 00 \\
65 \pm 8 \cdot 84 \\
52 \pm 19 \cdot 00\end{array}$ & $\begin{array}{l}2 \cdot 7 \pm 0 \cdot 145 \\
3 \cdot 0 \pm 0.348 \\
2 \cdot 4 \pm 0 \cdot 191 \\
1 \cdot 3 \pm 0.290 \\
2 \cdot 8 \pm 0 \cdot 168 \\
2 \cdot 3 \pm 0.050 \\
2 \cdot 8 \pm 0 \cdot 159 \\
2 \cdot 5 \pm 0.500\end{array}$ & $\begin{array}{l}0.48 \pm 0.035 \\
0.44 \pm 0.067 \\
0.44 \pm 0.075 \\
0.47 \pm 0.145 \\
0.57 \pm 0.081 \\
0.41 \pm 0.165 \\
0.40 \pm 0.083 \\
0.74 \pm 0.290\end{array}$ \\
\hline $\begin{array}{l}\text { Spinal canal tumours } \\
\text { Extramedullary tumours }\end{array}$ & 20 & $238 \pm 72 \cdot 92$ & $4 \cdot 5 \pm 0 \cdot 624$ & $0 \cdot 57 \pm 0.049$ \\
\hline $\begin{array}{l}\text { Meningioma } \\
\text { Neurinoma } \\
\text { Miscellaneous } \dagger\end{array}$ & $\begin{array}{l}6 \\
4 \\
3\end{array}$ & $\begin{array}{l}161 \pm 50 \cdot 81 \\
487 \pm 96 \cdot 98 \\
144 \pm 45 \cdot 31\end{array}$ & $\begin{array}{l}4 \cdot 1 \pm 0.965 \\
7 \cdot 3 \pm 2 \cdot 313 \\
3 \cdot 5 \pm 0 \cdot 883\end{array}$ & $\begin{array}{l}0.29 \pm 0.027 \\
0.69 \pm 0.145 \\
0.59 \pm 0.054\end{array}$ \\
\hline $\begin{array}{l}\text { Intramedullary tumours } \\
\text { Unknown } \\
\text { Ependymoma }\end{array}$ & $\begin{array}{l}6 \\
1\end{array}$ & $\begin{array}{l}65 \pm 14 \cdot 68 \\
229\end{array}$ & $\begin{array}{l}3 \cdot 4 \pm 0 \cdot 533 \\
4 \cdot 0\end{array}$ & $\begin{array}{l}0.58 \pm 0.070 \\
0.61\end{array}$ \\
\hline
\end{tabular}

Values are given as mean \pm SEM

* Haemangioma (1); congenital cystic tumour (1).

† Haemangioma (1); lipoma (1); metastatic tumour (1).

and the metastatic tumours. Also ependymomas contained lower amounts of beta-trace protein than astrocytomas and oligodendrogliomas. The ratio of the concentration of water soluble betatrace protein in astrocytomas, oligodendrogliomas, and gliomas to the other tumours was $58: 1$. Three times higher values of water soluble beta-trace protein were also found in the glialcell tumours than in normal white CNS matter.

No immunofluorescence for the beta-trace protein could be seen in nerve cells of cerebral monkey cortex, although specific immunofluorescence was seen in the neuropil. As exemplified in the Figure, (a) and (b), specific immunofluorescence for the beta-trace protein was localized to cells of a morphological appearance, such as that of astrocytes and oligodendrocytes. In sections from monkey cerebellum, no immunofluorescence could be seen in Purkinje cells, whereas specific fluorescence for the betatrace protein was seen in the granular layer.

The present results from normal human nervous tissue, using quantitative studies on neuronal and glial preparations, and from normal monkey nervous tissue, using qualitative immunofluorescence studies, together with quantitative studies on pathological nervous tissue, indicate that beta-trace protein is predominantly of glial cells origin, although it is also present to some extent in the neurones.

Table 4 lists the concentrations of beta-trace protein in CSF and serum and the total protein content in CSF. Significantly higher $(P<0.01)$ total protein content was found in patients with CNS tumours than in healthy controls. Within the group of patients with brain tumours, the highest concentrations of beta-trace protein were found in CSF from patients with malignant gliomas, but the values did not differ significantly from those found in CSF from patients with other brain tumours or from the controls. Significantly $(P<0.05)$ higher concentrations of beta-trace protein in CSF were found in patients with intraspinal tumours, especially in CSF from patients with extramedullary neurinomas. The serum concentrations of beta-trace protein were slightly higher in patients with intraspinal tumours, but did not differ significantly from patients with brain tumours or in the healthy controls.

\section{DISCUSSION}

Some years after the demonstration of beta- 
trace protein in CSF (Clausen, 1961; Hochwald and Thorbecke, 1962), it could be found in extracts of human brain with the aid of immunoelectrophoresis (Laterre et al., 1964). By means of the double immunodiffusion technique, Penny and Osserman (1971) demonstrated betatrace protein as weak precipitates in extracts of normal kidney, brain, fimbriae of Fallopian tubes, ovary, testis, and pancreas. Recently, the concentration of beta-trace protein in extracts from different human organs has been determined in relation to both the wet weight of the organ and the extracted amounts of water soluble proteins from the organ (Olsson and Nord, 1973). This investigation shows that the highest amounts of beta-trace protein are within the white CNS matter, but that other organs, too, contain beta-trace protein in higher amounts than justifies the calling of beta-trace protein brain-specific. Especially high amounts of betatrace protein were found within the genital organs, particularly the epididymis. These measurements were performed with single radial immunodiffusion on agar, according to Mancini et al. (1964) and gave values somewhat higher than those received by the complement fixation method used in this investigation. However, the same relative differences in protein concentration between grey and white CNS matter and epididymis were obtained for both methods. The highest concentration of beta-trace protein was demonstrated in extracts of white CNS matter, whereas extracts of grey matter and epididymis contained lower, but almost equal, amounts of beta-trace protein. The high concentration in epididymis and other genital organs is obvious, but the functional importance of this is still uncertain (Olsson and Nord, 1973).

The high concentration of beta-trace protein in CSF and the remarkable differences in concentration between human CSF and human serum make the CNS distribution of the protein as interesting as the CNS distribution of the brainspecific proteins. Many such proteins have been described during the past decade. The best known is an acidic protein, the $\mathrm{S}-100$ protein (Moore, 1965), called 'S-100' on the basis of its solubility in $100 \%$ saturated ammonium sulphate. It is only slightly smaller than beta-trace protein and has a molecular weight of 19,500 24,000 (Moore, 1969; Stewart, 1972). Several studies have described a glial cell origin of S-100 protein; it is also present in glial cell tumours of human brain (Hydén and McEwen, 1966; Benda, 1968; Cicero et al., 1969; Lightbody et al., 1970; Haglid and Carlsson, 1971; Haglid et al., 1973), although it is also claimed to be present to some extent in neurones (Hydén and McEwen, 1966; Packman et al., 1971; Sviridov et al., 1972; Haglid and Stavrou, 1973). In the present investigation, we found a similar cellular distribution of beta-trace protein within normal brain tissue and in different tumours. Because of this, also the concentrations of the $\mathrm{S}-100$ protein earlier found by Haglid et al. (1973) have been given in Tables 2 and 3 . The amounts of the S-100 protein were higher in the different normal brain fractions than beta-trace protein, but the proportions were almost identical.

In the brain tumours, the concentration of beta-trace protein was somewhat higher than that of S-100 protein in the tumours derived from glial cells, whereas the appearance of S-100 in other tumours was less frequent than that of beta-trace protein. This can be explained by a higher affinity of the S-100 protein to different nervous cells. S-100 is also very sparsely represented in CSF, whereas beta-trace protein is one of the major CSF proteins, indicating a higher leakage from CNS into CSF for the latter protein. The presence of beta-trace protein in tumours of a cellular origin other than glial cells might be caused by leakage into the tumour mass. The influence of CSF contamination must therefore be higher for beta-trace protein than for S-100. Although the tumours were carefully dissected from other tissues, small pieces of normal human brain could have been left at the random zone of the tumour or as islands within the tumour. Such contaminations could also explain small contents of the protein in some of the tumours not derived from glial cells.

However, the differences in amounts of betatrace protein in glial cell tumours and other tumours are quite distinct. The glial cell tumours also contained higher amounts of beta-trace protein than did normal white brain matter. This could be due to the higher density of glial cells in these tumours than in white CNS matter.

As proposed for the $\mathrm{S}-100$ protein, estimates of the beta-trace protein in different tumours of the nervous system might be an aid for the 
evaluation of the histogenetic background of the tumour (Haglid et al., 1973). These findings also suggest the site of synthesis. Recent studies of the synthesis of beta-trace protein within the CNS have also shown that the white CNS matter is able to produce the protein, whereas the grey CNS matter lacks this ability (Olsson and Sandberg-Wollheim, to be published).

Findings of a stronger specific immunofluorescence within white CNS matter than in grey CNS matter have been reported previously (Olsson and Nord, 1973). A higher purity of the antiserum against beta-trace protein, used in this investigation, and some changes in the immunofluorescence technique made it possible to find specific immunofluorescence at the cellular level. The findings of specific immunofluorescence in astrocytes and oligodendrocytes compared with that of nerve cells is in agreement with the quantitative results from fractions enriched in glial and neuronal cells and with results achieved with extracts of tumours derived from glial cells. These results also indicate that beta-trace protein is probably synthesized by glial cells.

The higher amounts of beta-trace protein found in white CNS matter suggest that the betatrace protein is involved in glia-myelin relation as increased concentrations of beta-trace protein in CSF during exacerbations of multiple sclerosis (Olsson and Link, 1973b) and after a stroke (Ericsson et al., 1969; Link and Olsson, 1972) have been demonstrated. The sparse quantity of beta-trace protein in the peripheral nervous system (Olsson and Nord, 1973) indicates that this protein is solely involved in myelin metabolism of CNS. This may well be a reflection of embryonal derivation of Schwann cells compared with oligodendroglial cells.

The findings of considerably higher amounts of beta-trace protein within tumours of glial cells origin could only be detected in CSF as slightly higher concentrations of the protein in CSF of patients with malignant gliomas. The lack of significantly increased concentrations of beta-trace protein in CSF from patients with gliomas is possibly due to the short turnover time in CSF of beta-trace protein, recently determined at about three hours (Olsson et al., 1973). Thus there must be very high amounts of beta-trace protein leaking from the tumour to the CSF to give significant amounts of the protein in CSF.
The significantly increased values of beta-trace protein in CSF from patients with intraspinal tumours might be due to a longer turnover time of the protein in CSF in patients with tumours that cause an incomplete or complete subarachnoidal block. The increased concentrations of beta-trace protein in CSF cannot be explained by transudation of the protein from serum to CSF, as the concentration in serum is seven times lower than in CSF (Olsson et al., 1973).

However, even if determination of the concentration of beta-trace protein in CSF does not provide any positive information of different brain tumours, the present findings of significantly higher amounts of beta-trace protein in tumours of glial cells origin and the earlier reports of significantly higher levels of S-100 protein in astrocytomas (Haglid et al., 1973) indicate that a chemical investigation of brain tumours or biopsies can complement the microscopic examination.

\section{SUMMARY}

Beta-trace protein constitutes about $7 \%$ of the total CSF protein content, whereas the serum concentration is only one-seventh of that in CSF. The highest amounts of beta-trace protein are found within white CNS matter; but also grey CNS matter and some genital organs, especially epididymis, contain rather high amounts of the protein.

In the present investigation, beta-trace protein was found in a concentration three times higher in fractions enriched in human glial cells than in fractions enriched in neuronal cells. By means of immunofluorescence on normal squirrel monkey brain, specific fluorescence was seen in glial cells, particularly in those resembling astrocytes and oligodendrocytes. In pathological human brain tissue consisting of different brain tumours, betatrace protein was found in significantly higher concentrations in tumours derived from glial cells than in tumours of other origin-for example, meningiomas and metastatic tumours. These findings are not reflected in CSF.

The present investigations of normal human and monkey brains, as well as pathological human brain tissues, show that beta-trace protein is predominantly of glial cells origin, although, to some extent, it is also present in 
neuronal tissue. The high concentrations in glial cell tumours may be of diagnostic value.

This work was supported by grants from the Swedish Multiple Sclerosis Society, Swedish Medical Research Council (Project B73-12X-3929-01), and Riksföreningen mot Cancer, grant No. 72-96.

\section{REFERENCES}

Bailey, J. L. (1963). Techniques in Protein Chemistry, p. 293. Elsevier: Amsterdam.

Benda, P. (1968). Protéine S-100 et tumeurs cérébrales humaines. Revue Neurologique, 118, 368-372.

Blomstrand, C., and Hamberger, A. (1969). Protein turnover in cell-enriched fractions from rabbit brain. Journal of Neurochemistry, 16, 1401-1407.

Blomstrand, C., and Hamberger, A. (1970). Amino acid incorporation in vitro into protein of neuronal and glial cell-enriched fractions. Journal of Neurochemistry, 17, 1187-1195.

Cicero, T. J., Cowan, W. M., Moore, B. W., and Suntzeff, V. (1970). The cellular localization of the two brain specific proteins, S-100 and 14-3-2. Brain Research, 18, 25-34.

Clausen, J. (1961). Proteins in normal cerebrospinal fluid not found in serum. Proceedings of the Society for Experimental Biology and Medicine, 107, 170-172.

Coons, A. H. (1957). The application of fluorescent antibodies to the study of naturally occurring antibodies. Annals of the New York Academy of Sciences, 69, 658-662.

Coons, A. H. (1958). Fluorescent antibodies methods. In General Cytochemical Methods, Vol. 1, pp. 399-422. Edited by J. F. Danielli. Academic Press: New York.

Ericsson, J., Link, H., and Zettervall, O. (1969). Urinary excretion of a low molecular weight protein in cerebral damage. Neurology (Minneap.), 19, 606-610.

Haglid, K. G., and Carlsson, C. A. (1971). An immunological study of some human brain tumours concerning the brain specific protein $\mathrm{S}_{100}$. Neurochirurgia, 14, 24-27.

Haglid, K. G., and Stavrou, D. (1973). Water-soluble and pentanol-extractable proteins in human brain normal tissue and human brain tumours, with special reference to the S-100 protein. Journal of Neurochemistry, 20, 15231532.

Haglid, K. G., Stavrou, D., Rönnbäck, L., Carlsson, C.-A., and Weidenbach, W. (1973). The S-100 protein in watersoluble and pentanol-extractable found in normal human brain and tumours of the human nervous system. A quantitative study. Journal of Neurological Sciences, 20, 103-111.

Hochwald, G. M., and Thorbecke, G. J. (1962). Use of an antiserum against cerebrospinal fluid in demonstration of trace proteins in biological fluids. Proceedings of the Society for Experimental Biology and Medicine, 109, 91-95.

Hydén, H., and McEwen, B. (1966). A glial protein specific for the nervous system. Proceedings of the National Academy of Sciences, 55, 354-358.

Laterre, E. C., Heremans, J. F., and Carbonara, A. (1964). Immunological comparison of some proteins found in cerebrospinal fluid, urine and extracts from brain and kidney. Clinica Chimica Acta, 10, 197-209.

Lightbody, J., Pfeiffer, S. E., Kornblith, P. L., and Herschman, H. (1970). Biochemically differentiated clonal human glial cells in tissue culture. Journal of Neurobiology, 4, 411-417.
Link, H. (1967). Immunoglobulin $G$ and low molecular weight proteins in human cerebrospinal fluid. Chemical and immunological characterisation with special reference to multiple sclerosis. Acta Neurologica Scandinavica, 43, Suppl. 28.

Link, H., and Müller, R. (1971). Immunoglobulins in multiple sclerosis and infections of the nervous system. Archives of Neurology (Chic.), 25, 326-344.

Link, H., and Olsson, J.-E. (1972). Beta-trace protein concentration in CSF in neurological disorders. Acta Neurologica Scandinavica, 48, 57-68.

Lowry, O. H., Rosebrough, N. J., Farr, A. L., and Randall, R. J. (1951). Protein measurement with the Folin phenol reagent. Journal of Biological Chemistry, 193, 265-275.

Mancini, G., Vaerman, J.-P., Carbonara, A. O., and Heremans, J. F. (1964). A single-radial-diffusion method for the immunological quantitation of proteins. In Protides of the Biological Fluids, pp. 370-373. Edited by H. Peters. Elsevier: Amsterdam.

Moore, B. W. (1965). A soluble protein characteristic of the nervous system. Biochemical and Biophysical Research Communications, 19, 739-744.

Moore, B. W. (1969). Acidic proteins. In Handbook of Neurochemistry, Vol. 1, pp. 93-99. Edited by A. Lajtha. Plenum Press: New York.

Moore, B. W., and Perez, V. J. (1966). Complement fixation for antigens on a picogram level. Journal of Immunology, 96, $1000-1005$.

Moore, B. W., and Perez, V. J. (1968). Specific acidic proteins of the nervous system. In Physiological and Biochemical Aspects of Nervous Integration, pp. 343-359. Edited by F. O. Carlson. Prentice-Hall: Englewood Cliffs, New Jersey.

Olsson, J.-E., and Link, H. (1973a). Distribution of serum proteins and beta-trace protein within the nervous system. Journal of Neurochemistry, 20, 837-846.

Olsson, J.-E., and Link, H. (1973b), Immunoglobulin abnormalities in multiple sclerosis. Relation to clinical parameters: exacerbations and remissions. Archives of Neurology (Chic.), 28, 382-399.

Olsson, J.-E., Link, H., and Nosslin, B. (1973). Metabolic studies on $\left.{ }^{[125} \mathrm{I}\right]$ beta-trace protein, with special reference to synthesis within the central nervous system. Journal of Neurochemistry, 21, 1153-1159.

Olsson, J.-E., and Nord, L. (1973). Immunochemical and immunofluorescence studies of beta-trace protein in different species and organs, with special reference to the central nervous system. Journal of Neurochemistry, 21, 625-633.

Ouchterlony, Ö. (1948). In vitro method for testing the toxinproducing capacity of diphtheria bacteria. Acta Pathologica et Microbiologica Scandinavica, 25, 186-191.

Packman, P. M., Blomstrand, C., and Hamberger, A. (1971). Disc electrophoretic separation of proteins in neuronal, glial and subcellular fractions from cerebral cortex. Journal of Neurochemistry, 18, 479-487.

Penny, R., and Osserman, E. F. (1971). Studies on beta-trace protein. Australian Journal of Experimental Biology and Medical Science, 49, 111-120.

Sviridov, S. M., Korochkin, L. I., Ivanov, V. N., Maletskaya, E. I., and Bakhtina, T. K. (1972). Immunohistochemical studies of $\mathrm{S}-100$ protein during postnatal ontogenesis of the brain of two strains of rats. Journal of Neurochemistry, 19, 713-718. 
Stewart, J. A. (1972). Tissue specific brain S-100. A demonstration of multiple proteins. Biochimica et Biophysica Acta, 263, 178-192.

Warecha, K., and Bauer, H. (1966). Studien über Hirnproteine. Immunochemische Untersuchungen der wasser- löslichen Fraktionen. Deutsche Zeitschrift für Nervenheilkunde, 189, 53-66.

Wieme, R. J. (1959). An improved technique of agar-gel electrophoresis on microscope slides. Clinica Chimica Acta, 4, 317-321. 